\title{
PEMBERDAYAAN KELOMPOK NELAYAN TANGKAP TRADISIONAL DI KAWASAN PESISIR PANTAI MORO DEMAK DALAM UAPAYA PENINGKATAN PRODUKSI DAN PENGHEMATAN BBM
}

\author{
Eko Sasmito Hadi ${ }^{1)}$, Imam Pujo Mulyatno ${ }^{1)}$, Ari Wibawa Budi Santosa ${ }^{1)}$ \\ ${ }^{1)}$ Dosen Teknik Perkapalan, Fakultas Teknik, Universitas Diponegoro \\ Email : ekosasmito@kapal.ft.undip.ac.id, pujomulyatno2@gmail.com, Arikapal75@gmail.com
}

\begin{abstract}
Abstrak
Mitra dari kegiatan pengabdian masyarakat yang merupakan kelompok nelayan yang tergabung dalam KUD Mino Utomo dan paguyuban nelayan kabupaten Demak. Karya utama dalam kegiatan ini adalah alat pemanggil ikan berupa lampu celup dengan dilengkapi solarsel sebagai sumber energi alternatif pengganti BBM yang ramah lingkungan. Peralatan ini dirancang sebagai lampu atraktor yang dapat meningkatkan hasil tangkapan dan mengurangi biaya operasional. Lampu tersebut dapat di turunkan ke dalam air sampai kedalaman tertentu. Sistim pencahayaan ikan menggunakan lampu listrik dalam air bertenaga surya yang telah dibuat teridiri dari : satu paket lacuba terdiri dari 2 (dua) buah lampu, 1 (satu) buah converter, kabel masing-masing untuk 1 (satu) lampu sepanjang 15 meter, 1 (satu) buah charger, untuk pengisian $\mathrm{accu}$.

Dengan adanya alat ini nelayan tidak tergantung pada bahan bakar minyak bumi (BBM), dapat menekan biaya operasional dan akhirnya dapat meningkatkan kesejahteraan nelayan.
\end{abstract}

Kata kunci : Solarsel, lampu atraktor, BBM, nelayan

\section{PENDAHULUAN}

Sejak kenaikan harga bahan bakar minyak (BBM) ekonomi nelayan kecil dan buruh pencari ikan dipastikan semakin tertekan. Kondisi mereka kian memprihatinkan tatkala pasokan minyak tanah yang menjadi alternatif pengganti solar untuk bahan bakar melaut sulit untuk didapat. Awalnya mereka masih bisa membeli bahan bakar perahu, campuran solar dan minyak tanah. Namun, belakangan ini mereka sudah tak mampu membeli solar. Harga eceran solar lebih mahal jika dibandingkan dengan harga minyak tanah. Sekali melaut, nelayan-nelayan kecil berperahu 12-16 PK ini menghabiskan 25 liter solar.

Potensi kelautan Kabupaten Demak khususnya perikanan tangkap meliputi wilayah pantai utara sepanjang $57 \mathrm{Km}$, Jumlah TPI/PPI 2 buah, 3.888 Armada kapal, 24.786 Orang berprofesi sebagai Nelayan, Bakul Ikan di TPI/PPI ada 139 orang. Sedangkan jumlah alat penangkap ikan terdiri dari gill Net 129 buah, payang 641 buah, bundes 28 buah, klitik 973 buah, cantrang 219 buah. Program IbM ini mengarah kepada Pengembangan Usaha
Penangkapan Ikan melalui penerapan teknologi/ modernisasi alat tangkap yang ramah lingkungan.

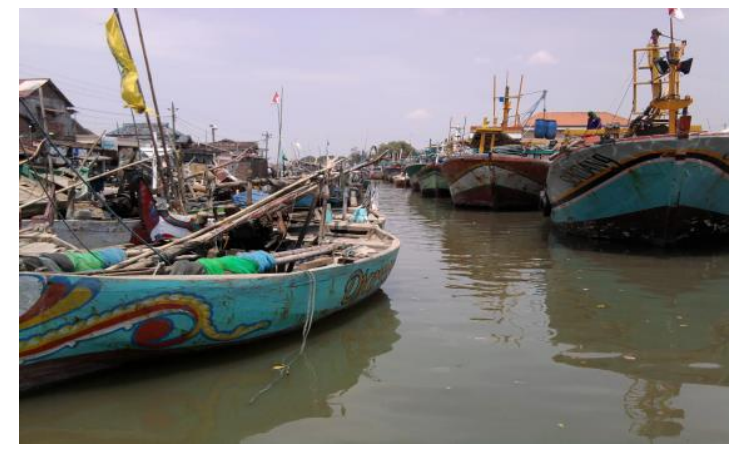

Gambar 1. Foto Kapal Milik Nelayan yang menjadi Mitra

Dampak kenaikan harga BBM sangat memukul perekonomian nelayan di Kota demak. Sejak pekan terakhir ini, ribuan nelayan tidak melaut, karena selalu merugi dan terus-menerus menanggung utang. Modal habis, solar susah didapat, harga solar naik, ikan tidak didapat. Jika 
dapat ikan, harganya murah sehingga setiap melaut merugi.

Permasalah tersebut dapat selesaikan dengan membuat rancang bangun lampu atraktor yang kedap air. Dengan adanya lampu atraktor yang kedap air diharapkan lampu tersebut dapat dioperasikan segala cuaca, bahkan lampu tersebut dapat diturunkan ke dalam air sampai kedalaman tertentu. Untuk sumber tenaga dari lampu atraktor, diambil dari sistem photovoltaik. Sistem photovoltaik akan mengkonversi langsung energi sinar matahari menjadi energi listrik.

\subsection{Perumusan Masalah}

Dari observasi dilapangan dan diskusi dengan Kelompok Nelayan yang tergabung dalam KUD Mino Utomo dan Paguyuban Nelayan Kabupaten Demak mengakui adanya beberapa persoalan yang dihadapi dikalangan masyarakat nelayan Kecamatan Wedung dan Bonang Demak, diantaranya :

1. Sering terjadi konflik sosial antara nelayan purse seine dan minipurse seine. Pengoperasian kapal purse seine menggunakan lampu atraktor yang dipasang di atas kapal dengan kekuatan 15.000-35.000 watt, bahkan nelayan cenderung memperbesar lampu atraktor yang digunakan. Lampu ditempatkan $3-4 \mathrm{~m}$ di atas permukaan laut menjadikan berkas cahaya terpantul. Hal ini akan menimbulkan kecemburuan sosial bagi nelayan skala kecil, yang pada akhirnya dapat memicu terjadinya konflik sosial. Nelayan kecil mini puse seine merasakan bahwa ikan-ikan didaerah tangkapannya tertarik oleh lampu purseseine yang sangat terang, akibatnya hasil tangkapanya selalu menurun.

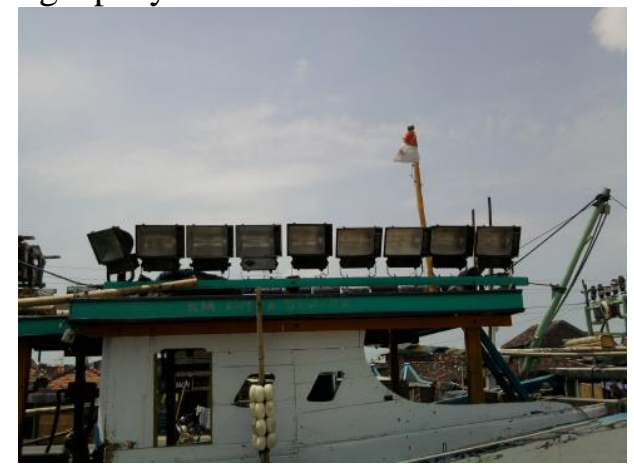

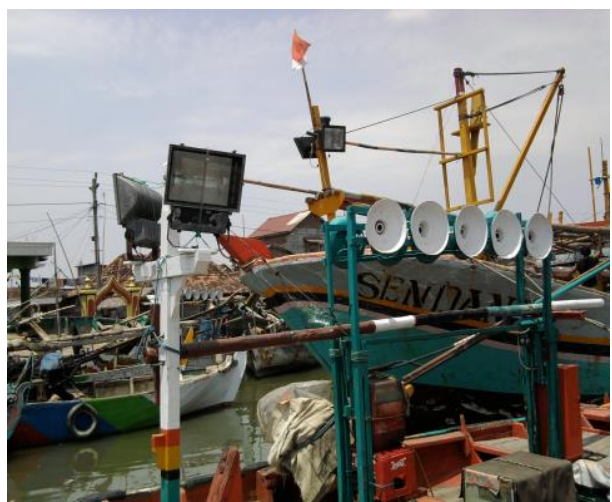

Gambar 2. Lampu yang menjadi Sumber Konflik antar Nelayan

2. Lampu Atraktor di atas permukaan laut yang sekarang ini digunakan pada kenyataannya kurang efektif, karena berkas cahayanya sebagaian besar akan terpantul oleh lapisan permukaan laut. Berdasarkan penelitian terdahulu pada saat di atas permukaan air pada jarak pengukuran $50 \mathrm{~m}$ dari sumber cahaya, nilai luminasi cahaya berkurang sebesar $\pm 98 \%$ (halogen) dan $\pm 99 \%$ (galaxy) ;nilai luminasi cahaya berkurang setelah menembus permukaan air, yaitu : sebesar 66 - 88\% (merkuri dan halogen), lebih dari $90 \%$ (galaxy). Sehingga diperlukan rekayasa rancang bangun lampu yang tercelup dalam air, yang memiliki bentuk dan konstruksi sederhana, sehingga mudah dioperasikan dan diterapkan oleh nelayan purse seine.

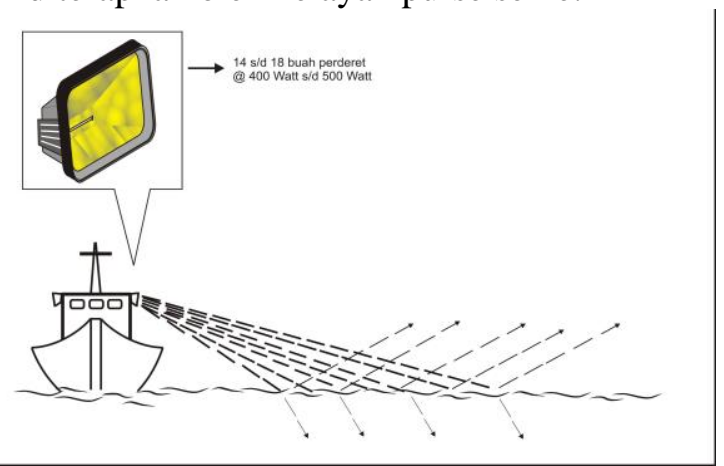

Gambar 3. Cahaya Lampu yang Sebagian

Besar Terpantulkan oleh Permukaan Laut

Melalui kegiatan KKN PPM ini nelayan penangkap ikan diharapkan dapat meninggalkan kebiasaan lama dan menggunakan alat bantu lampu pemanggil ikan. 


\subsection{Tujuan Dan Manfaat}

Tujuan dari kegiatan pengabdian ini adalah :

1. Mencegah terjadinya konflik antar nelayan dalam hal ini nelayan Demak.

2. Menghasilkan lampu atraktor yang dapat meningkatkan hasil tangkapan dan mengurangi biaya operasional. Sehingga nantinya dapat meningkatkan produktifitas dan tingkat kesejahteraan nelayan.

3. Perancangan dan pembuatan alat pemanggil ikan berupa lampu celup dengan dilengapi solar sel sebagai alternatif pengganti BBM.

4. Masyarakat nelayan ikan berpartisipasi dalam mengurangi polusi udara yang diakibatkan oleh udara emisi gas buang yang dihasilkan oleh mesin yang menggunakan BBM.

5. Peningkatan kualitas dan kuantitas hasil tangkapan (ikan) dengan adanya investasi peralatan lampu celup solar sel.

Manfaat dari kegiatan pengabdian ini adalah :

1. Dengan pemakaian lampu atraktor yang kedap air dengan sumber energi dari sistem fotovoltaik, akan menghasilkan lampu atraktor yang dapat meningkatkan hasil tangkapan dan mengurangi biaya operasional. Sehingga dapat meningkatkan produktifitas dan tingkat kesejahteraan nelayan.

2. Dengan adanya alat ini nelayan tidak tergantung pada bahan bakar minyak bumi (BBM), dapat menekan biaya operasional dan akhirnya dapat meningkatkan kesejahteraan komunitas nelayan.

3. Lampu atraktor yang biasanya ditempatkan di atas kapal purse seine dapat dikurangi jumlahnya sehingga dapat mengurangi/ meredam kecemburuan sosial terhadap nelayan skala kecil yang beroperasi di perairan pantai.

\section{KERANGKA PENYELESAIAN MASALAH}

Untuk mencapai tujuan dari kegiatan yang telah ditetapkan metode pendekatan yang digunakan adalah didasarkan pada analisis situasi kelompok sasaran (masalah, potensi dan peluang). Setelah melakukan evaluasi terhadap hasil tangkapan yang diperoleh nelayan selama ini, maka tim pelaksana KKN - PPM melaksanakan kegiatan sebagai berikut :

\subsection{Rancang Bangun Alat}

Lampu celup bawah air/ dalam air didesain sebagai alat daya tarik mengumpulkan ikan sekaligus untuk meningkatkan hasil tangkapan bagi para nelayan. Lampu dibuat kedap sehingga tidak terjadi hubung singkat yang dapat membahayakan nelayan.

Satu paket lacuba terdiri dari :

- 2 (dua) buah lampu.

- 1 (satu) buah converter.

- Kabel masing-masing untuk 1 (satu) lampu sepanjang 15 meter.

- 1 (satu) buah charger, untuk pengisian accu. Jumlah alat bantu pengumpul ikan/ lampu celup bawah air yang diperlukan tergantung kebutuhan para nelayan serta kondisi serta ukuran Perahu.

\section{a. Pra Perancangan Alat}

Kegiatan ini dilakukan dengan di laboratorum Sistem Kelistrikan Kapal Teknik Perkapalan Fakultas Teknik UNDIP. Percobaan dilakukan dengan melakukan variasi terhadap kondisi operasional dilapangan yang meliputi daya yang diperlukan, kekedapan lampu celup dan jenis lampu yang akan dipakai. Karena hal yang penting untuk dikaji adalah :

1. Ukuran atau Dimensi

Parameter yang diperlukan adalah Panjang $(\mathrm{m})$, lebar $(\mathrm{m})$, tebal $(\mathrm{m})$ dan berat $(\mathrm{kg})$ dari panel solar sel.

2. Besaran Parameter Listrik

Parameter listrik adalah daya (watt), tegangan (volt) dan kuat arus (ampere) yang mampu dihasilkan oleh solar sel pada kondisi yang diinginkan.

\section{b. Perangkaian Sistem}

Merupakan tahap perangkaian sistem secara keseluruhan, antara sistem fotovolaik dan lampu atraktor menjadi satu kesatuan utuh. Diagram sistem secara keseluruhan adalah : 


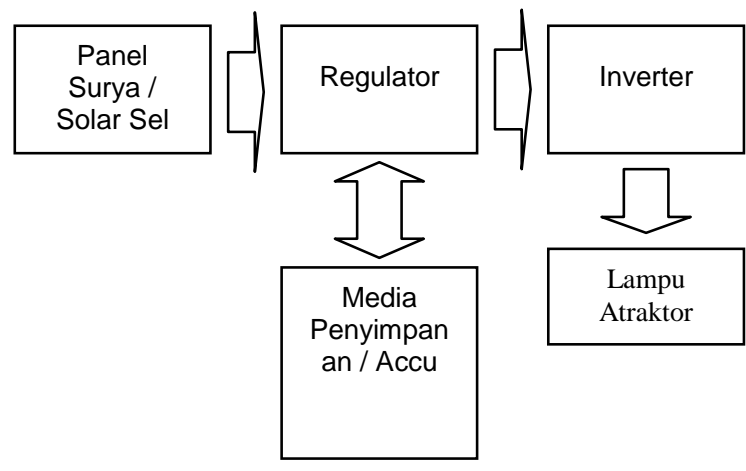

Keterangan :

1. Panel surya / solar sel

Merupakan alat yang mengkonversi langsung, sinar matahari menjadi energi listrik. Kapasitas atau daya solar sel telah ditentukan berdasarkan perhitungan teknis.

2. Regulator

Alat ini berfungsi sebagai pengatur aliran listrik dari solar sel ke media penyimpanan atau Accu, dan ke beban.

3. Media Penyimpanan / Accu

Alat ini berfungsi sebagai penyimpan energi listrik yang telah dihasilkan oleh solar sel. Kapasitas Accu ditentukan berdasarkan pola penyalaan lampu atraktor.

4. Inverter

Inverter merupakan alat yang mengubah arus listrik DC ke AC. Alat ini mengubah dari tegangan $12 \mathrm{~V}$ DC ke $220 \mathrm{~V}$ AC, sedangkan kapasitas Inverter berdasarkan daya lampu atraktor. Diusahakan alat ini menggunakan komponen yang banyak dijumpai dipasaran.

5. Lampu Atraktor

- Lampu mudah didapatkan dipasaran dan terjangkau oleh masyarakat, diusahakan menggunakan sistem AC dengan besar tegangan 220 Volt.

- Mudah dalam pemasangan dan penggunaannya.

- Mempunyai teknologi yang mudah dimengerti oleh masyarakat awam.

\section{c. Demontrasi Ploting di Kelompok Mitra}

Kegiatan ini bertujuan untuk meningkatkan sumber daya manusia UKM mitra agar mampu mandiri dalam hal pengoperasian serta pemeliharaan alat tersebut. Adanya pelatihan ini diharapkan juga anggota UKM dapat memperoleh bekal dalam pengoperasikan Lampu celup pemanggil ikan.

\section{d. Pelatihan Pengembangan Usaha}

Pelatihan Pengembangan Usaha bertujuan untuk mendapatkan kelayakan secara ekonomi dengan adanya investasi peralatan tersebut. Dalam Pelatihan ini UKM memperoleh penjelasan berapa keuntungan yang diperoleh, waktu balik modal, POT (Pay Out Time).dan kiat-kiat untuk meningkatkan usahanya.

\section{METODOLOGI}

Untuk melaksanakan metode pemecahan masalah dibedakan atas lima tahap yaitu :

1. Analisis dan evaluasi pada dua kelompok sasaran dalam hal ini nelayan Demak. Kegiatan ini sebagai sudah dilaksanakan, namun untuk memperoleh hasil yang lebih menyeluruh perlu dilkuakan evaluasi secara detail.

2. Perancangan dan pembuatan alat pemanggil ikan berupa lampu celup dengan dilengapi solar sel sebagai alternatif pengganti BBM.

3. Pelatihan tentang proses pembuatan dan operasional alat.

4. Demonstrasi dan plotting alat di UKM sasaran.

5. Monitoring/ pendampingan.

\subsection{PELAKSANAAN KEGIATAN}

Metode pelaksanaan KKN PPM dalam bentuk program-program yang dilaksanakan bersama Tim Pelaksana Program KKN UNDIP dan kelompok masyarakat nelayan dapat mengolah sumberdaya ikan yang berwawasan lingkungan akan dilaksanakan sebagai berikut :

\subsubsection{Persiapan Pembekalan KKN-PPM}

Pada kegiatan pembekalan KKN-PPM ini mahasiswa mendapatkan pembekalan materi dan pemberdayaan masyarakat. Diharapkan dari pembekalan tersebut maka mahasiswa mampu memberdayakan masyarakat nelayan dalam penggunaan teknologi penangkapan ikan yang ramah lingkuan (solar sell).

\subsubsection{Pelaksanaan Kegiatan KKN-PPM}

Tim pengabdian telah melaksanakan beberapa kegiatan, diantaranya : 
a. Sosialisasi dan penyuluhan tentang pemanfaatan energi alternatif solar sell, dan pengenalan data spesifikasi teknis fotovoltaik atau solar sel.

b. Pembuatan Alat dan pengujian di laboratorium.

c. Pelatihan pemakaian alat dan aplikasinya di kapal perikanan.

d. Pelatihan penggunaan alat keselamatan kapal di laut bagi para nelayan demak.

\subsubsection{Rencana Keberlanjutan Program KKN-PPM}

Keberlanjutan program KKN-PPM ini sejalan dengan Tri Dharma perguruan tinggi Universitas Diponegoro dimana program KKN PPM merupakan matakuliah wajib yang bisa diintegrasikan dengan pengabdian kepada masyarakat nelayan yang masih minim perhatian dari pemerintah.

\section{HASIL DAN PEMBAHASAN}

Pelaksanaan KKN PPM diawali dengan beberapa agenda diantaranya pembekalan, survey lokasi, dan pelepasan mahasiswa KKN PPM. Pembekalan dilakukan untuk memberikan gambaran pelaksanaan KKN PPM dari dosen kepada mahasiswa sebagai pelaksana. Pembekalan dilakukan 5 kali yaitu pada tanggal 8, 12, 15, 16 dan 31 Mei 2015 dengan narasumber dari beberapa dosen UNDIP, LPPM, BBPI dan yang bersangkutan dengan program yang akan dilakukan, dengan harapan mahasiswa dapat mengerti dan melaksanakan sesuai target yang akan dicapai. Pada tahap pembekalan ini dijelaskan tentang pelaksanaan survey yaitu sebagai tahapan sebelum pelaksanaan yang wajib dilakukan untuk memberikan gambaran nyata masalah yang terjadi di Desa Purworejo kepada mahasiswa yang bersangkutan. Tentunya dengan survey ini akan ditemukan gambaran permasalahan dan solusi dengan pelaksanaan program KKN yang sasarannya untuk mencapai target yang ingin dicapai. selanjutnya dilanjutkan dengan acara pelepasan mahasiswa sebagai bentuk simbolis penerjunan mahasiswa KKN PPM di Desa Purworejo.

Sejak pekan terakhir ini masyarakat nelayan jarang pergi berlayar, ini dikarenakan menurunnya hasil tangkapan ikan yang diperoleh. Hal ini disebabkan karena mahalnya harga solar yang tidak sebanding dengan jumlah ikan yang didapat sehingga masyarakat rugi biaya operasional sampai harus hutang solar ke agen BBM sebagai modal untuk pergi berlayar, setelah pulang berlayar maka hasil tangkapan ikan yang mereka dapat dijual untuk mengganti hutang solar yang telah dipakai sebelumnya. Dari permasalah tersebut dapat dicarikan solusi dengan cara menggunakan alat yang dapat embantu untuk mengumpulkan ikan yaitu dengan lampu yang kedap air, metode lampu celup ini efektif untuk merangsang ikan- ikan untuk mendekati sinar sehingga diharapkan dapat meningkatkan hasil tangkapan para nelayan dan manfaat lain yang dapat diperoleh dengan menggunakan lampu celup ini yaitu energi listrik yang digunakan dihasilkan dari energi radiasi panas matahari sehingga dapat meminimalkan biaya pengeluaran para nelayan. Solar Cell yaitu suatu alat yang menghasilkan energi listrik dengan memanfaatkan sinar radiasi matahari sehingga lebih murah, efisien, dan ramah lingkungan. Dengan penggunaan solar cell nelayan tidak memerlukan biaya operasional yang banyak karena alat ini hanya mengandalkan energi sinar matahari.
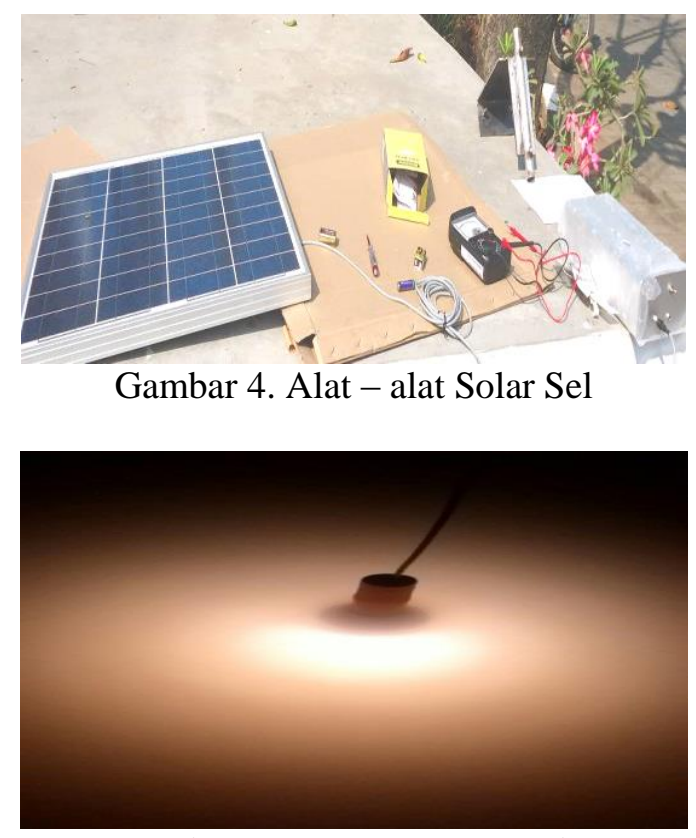

Gambar 5. Penggunaan Lacuba 


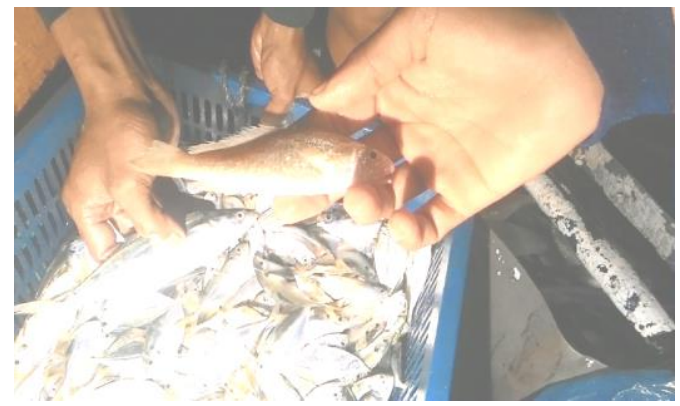

Gambar 6. Hasil Tangkapan Ikan menggunakan Lacuba

\subsection{Teknik Penanaman Mangrove dengan Bis Bambu}

Program penanaman mangrove dilaksanakan di area Pantai Sigandu Kab. Batang yang lokasinya masih disekitar sentra industri kapal batang. Disekiling pantai ini terdapat tanaman tanaman mangrove yang tumbuh disepanjang pantai, namun banyak lahan lahan yang belum ditanami, sehingga lokasi ini sangatlah cocok untuk ditanami mangrove yang difungsikan untuk menahan abrasi pantai. Teknik penanaman mangrove yang dilakukan adalah dengan menggunakan buis bambu sebagai mediatornya.

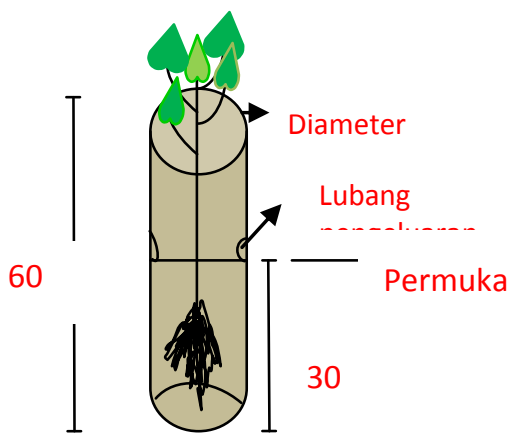

Gambar 8. Penyusunan bagian bibit mangrove yang akan ditanam.

Tahapan yang perlu diperhatikan dalam menanam mangrove tersebut yang pertama adalah survey lokasi dan ketepatan waktu, dalam halnya waktu kita harus memperhatikan pasang surut air laut. Dalam observasi lahan ini kita harus memperhatikan kondisi lahannya, hal ini dhanya dapat dilakukan dalam kondisi surut saja . setelah observasi lahan dan dipilih waktu yang tepat untuk menanam maka dilakukan persiapan bibit. Dalam persiapan bibit maka kita jenis bibit mangrove yang ada disana yang masih bagus. Dalam metode tepat guna ini juga kita menggunakan buis bambu maka harus mempersiapkan bambu yang telah di potong potong. Buis bambu harus mempunyai panjang $60 \mathrm{~cm}$ dan diameter $60 \mathrm{~cm}$ dan dipasang pada area dengan jarak tanam $2 \times 1 \mathrm{~m}$ normal dengan kedua ujung bambu tersebut dilubangi. Kemudian menancamkan buis bambu kedalam tanah dengan kedalaman sekitar $30 \mathrm{~cm}$.

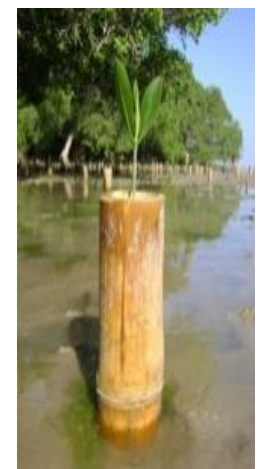

Gambar 7. Kegiatan dan gambaran kondisi di lokasi penanaman Mangrove

\begin{tabular}{|c|c|}
\hline Sebelum & Sesudah \\
\hline $\begin{array}{lr}\text { Nelayan } & \text { masih } \\
\text { bergantung } & \text { pada } \\
\text { BBM (adanya } & \text { krisis } \\
\text { BBM) } & \end{array}$ & $\begin{array}{lr}\text { Nelayan masih bisa } \\
\text { melaut } & \text { saat } \\
\text { kelangkaan } & \text { BBM } \\
\text { (Produksi } & \\
\text { Meningkat) } & \end{array}$ \\
\hline $\begin{array}{lll}\begin{array}{l}\text { Adanya } \\
\text { pantai }\end{array} & \text { abrasi } & \text { di } \\
\end{array}$ & $\begin{array}{l}\text { Mengurangi } \\
\text { abrasi,pelestarian } \\
\text { ekosistem } \\
\text { pantai,tempat } \\
\text { pelestarian ikan }\end{array}$ \\
\hline
\end{tabular}

\section{PENUTUP}

\subsection{Kesimpulan}

Kegiatan KKN PPM Tematik yang dilaksanakan di Desa Purworejo, Kecamatan Bonang, Demak telah terlaksana dengan baik. Pemberdayaan yang dilakukan tidak hanya tertuju pada nelayan saja namun juga untuk berbagai komponen masyarakat yang berada di desa Purworejo diantaranya ibu-ibu PKK, anak sekolah, kelompok mangrove, perangkat desa dan lain-lain. Respon yang diberikan oleh warga Desa Purworejo pun cukup baik terhadap program-program yang dijalankan baik itu program monodisiplin ataupun program 
multidisiplin dilihat dari antusiasme warga

dalam mengikuti program yang dijalankan

\subsection{Saran}

Pemakaian alat ini direkomendasi-kan untuk para nelayan kecil yang jarak dan lama pelayaranya tidak lama ( one day fishing). Pemasangan panel surya (solarsell) harus dipastikan dalam kondisi yang kokoh dan posisi kemiringan yang sesuai. Terutama untuk kapalkapal besar dengan jarak pelayaran yang jauh dan angin yang kencang. Akan lebih baik kalau posisi panel surya dapat fleksibel di gerakkan mengikuti arah datangnya sinar matahari, sehingga akan memaksimalkan pada saat pengisian aki.

\section{UCAPAN TERIMA KASIH}

Terima kasih disampaikan kepada Kementrian Riset, Teknologi dan Pendidikan Tinggi serta Ditjen Dikti Kementerian Pendidikan Nasional yang telah membiayai program pengabdian masyarakat ini.

\section{DAFTAR PUSTAKA}

[1] Anonim, 2007. "Fishing light attractor", Wikipedia ${ }^{\circledR}$ is a registered trademark of the Wikimedia Foundation, Inc.

[2] Ariawan, Pratama Risqi. 2008. Studi Awal System Hybrid Antara Diesel Engine Dengan Solar Cell Pada Kapal Penangkap Ikan.

[3] Sarwito, Sardono dkk. 2007. Pemanfaatan Sel Surya Sebagai Catu Daya Sistem Pendingin Mekanis Pada Kapal Ikan

[4] Sri Eko Wiyono, "Menangkap Ikan Menggunakan Cahaya" Mahasiswa Program Doktor Tokyo University of Marine Science and Technology Tokyo, (Email: eko_ipb@yahoo.com, diakses 208-2008

[5] Sulaiman Muhammad, 2007. "Pendekatan Akustik Dalam Studi Tingkah Laku Ikan Pada Proses Penangkapan Dengan Alat Bantu http://www.damandiri.co.id/

Cahaya, 